\title{
The Impact of Financial Fraud on Financial Risks: A Case Study of Luckin Coffee
}

\author{
Yingxiao Feng ${ }^{1, *}$, Changhao Chen ${ }^{2, * \dagger}$
}

\author{
${ }^{1}$ School of accounting, Harbin University of Commerce, Harbin, Heilongjiang 150028, China \\ ${ }^{2}$ School of finance, Hunan University of Finance and Economics, Changsha, Hunan 41000, China \\ *Yingxiao Feng:2426299038@qq.com; Changhao Chen: 793816023@qq.com \\ These authors contributed equally.
}

\begin{abstract}
On April 2, 2020, Luckin coffee issued a public statement acknowledging financial fraud which caused their stock price to collapse. This paper studies the cases of Luckin coffee's fraud, focusing on the analysis of the impact of financial fraud on the financial risks of enterprises. This paper uses the Altman's Z-score model and decomposes the firm's financial risks into five factors. It is shown that the inflated revenue can have a substantial impact on four of the factors which can mislead the investors. After the financial fraud, the reputation of an enterprise will be affected, which will reduce its financing ability in the future and eventually lead to an increase in its financial risks.
\end{abstract}

Keywords: Luckin Coffee; Financial Fraud on Financial Risks.

\section{INTRODUCTION}

As a new coffee company in China, Luckin coffee has already surpassed Starbucks and other coffee chains in the number of local stores since its establishment, and has a good development prospect. However, before the financial fraud was exposed, there had been signs of problems in its operation, which attracted the attention of the outside world. On February 1, 2020, Muddy Waters Research issued an 89-page short report against Luckin coffee, which sent the company's shares down 24 percent. On April 2, 2020, the fraudulent transactions of Luckin coffee company were exposed, involving a total amount of 2.2 billion yuan. The negative impact of financial fraud on the company's share price was very prominent, from foreign regulators to domestic netizens, Luckin coffee stock price fell and triggered the fuse mechanism, the total closing value was less than 1.6 billion US dollars, the subsequent malignant influence continued to expand. In 2020, Luckin coffee disclosed that the financial fraud sales amounted to 2.2 billion, which aroused media and social concern. In this paper, Z-Score model is used to analyze and estimate the probability of bankruptcy in Luckin coffee, so as to infer the impact of financial fraud on Luckin coffee's financial risks.

\subsection{Company Profile}

The first store in Luckin coffee opened in October 2017, and Luckin coffee was listed on NASDAQ on May 17,2019 . It was successfully listed in less than two years after its establishment, setting a record for the fastest listing of Chinese startups. Luckin coffee is committed to providing customers with high-quality, cost-effective, and convenient products by making full use of the new retail model of mobile Internet and big data technology. In January 2020, the number of direct-operated stores reached 4,507, making it the largest coffee chain brand in China. Luckin coffee had carried out many rounds of financing, with the help of strong capital to promote the rapid development of the company. In July 2018, the A round of financing of 200 million US dollars was completed, and the post-investment valuation was 1 billion US dollars; in December 2018, it completed Series B financing of USD 200 million, with a post-investment valuation of USD 2.2 billion. On April 2, 2020, Luckin coffee announced that it had set up a special committee to conduct internal investigation, and the preliminary investigation report of self-explosion showed that the sales increased by 2.2 billion yuan from the second quarter of 2019 to the fourth quarter of 2019. Liu Jian, chief operating officer (COO) and director of Luckin coffee, and several subordinate employees engaged in misconduct, including fabricating transactions. Affected 
by this, Luckin's stock price dropped by over $80 \%$, and its market value evaporated by nearly 5 billion US dollars. In the first three quarters of 2019, Luckin's main business income was 2.9 billion yuan, and now the fraud scale of 2.2 billion yuan in 2019 has approached the total revenue scale of the first three quarters. On May 19th, Luckin coffee was asked to delist from Nasdaq and apply for a hearing. On June 29th, Luckin coffee officially suspended trading and was delisted.

\subsection{Event analysis}

Luckin coffee, the case object of this paper, flaunted that he was implementing the business model of mobile Internet enterprise. In the early stage, it expanded rapidly through excessive subsidies in the product market, and was favored by investors in the capital market, and obtained an asymmetric valuation with the product market. However, in the process of business operation, excessive pursuit of catering to the valuation flow in the capital market and ignoring the construction of the core competitiveness of enterprises in the product market will result in weak user stickiness, making it impossible to form a resource aggregation consisting of product flow, information flow, capital flow and user flow, and it is difficult to build a collaborative innovation and value creation mechanism in the enterprise value chain; at the same time, the founder and management team of the company have the business ethics risk of cashing out personal wealth through the capital market. The lack of corporate governance risk management and control mechanism will lead to the financial fraud of the company.

As the stock market with the highest degree of marketization in the world, the delisting standards of the New York Stock Exchange are more market-oriented, and the delisting conditions are more biased towards indicators such as market value, number of shareholders and stock price, and the financial indicators account for a small proportion; stock delisting standards of Shanghai Stock Exchange pay more attention to financial indicators, such as net profit, net assets, and operating income, etc. Even if financial indicators are emphasized, some indicators are both flawed and complex. Why is it complicated? For example, if there is no clear indicator to measure non-recurring gains and losses, there are often enterprises that implement the profit model of "two years loss, one year profit and two years loss". If the listed company's net assets are losing money for three consecutive years, it must be forced to withdraw from the market; if there is no loss, but the operating income for three consecutive years is less than 10 million yuan, it is also necessary to withdraw from the market. Such a system indirectly gives listed companies a lot of operating space, which can avoid forced withdrawal from the market through selling assets and financial adjustment; or surprise trading at the end of the year, avoiding losses to protect the shell, and so on.

\subsection{Literature}

The financial fraud of Luckin Coffee has brought scholars to seriously think about the corporate governance in the era of mobile Internet. [1] Research has been done on the impact of such a financial fraud event. Yang reminded ordinary small and medium-sized investors to find out financial fraud in advance and avoid stepping on thunder by analyzing some public information such as financial statements through five parts: financial overview of Luckin coffee, single store income, gross profit margin analysis, commodity unit price, and sales analysis and inventory analysis [2]. Wang studies the impacts given a special pandemic period and finds the covid-19 pandemic can exacerbate the negative consequences [3].

By analyzing the current situation of financial fraud of listed companies in China, Wang and Chen studied the unique characteristics of blockchain technology, such as decentralization, distributed bookkeeping, openness and transparency, and unchangeable. They analyzed the positive impact of such characteristics on solving the problem of financial fraud, and put forward some suggestions on applying blockchain technology to solve the problem of financial fraud [4].

Cao studied the solutions and enlightenment of Luckin coffee's financial fraud against foreign investors from the perspective of foreign jurisdiction. Luckin coffee has damaged the rights and interests of some investors in China, but the Securities Law has no specific jurisdiction rules to track Luckin coffee In order to get rid of the aphasia dilemma of exercising extraterritorial jurisdiction of securities, we should learn from the "effect test standard" of American securities law on the basis of conforming to the international comity principle, and require that when the illegal acts of overseas securities reach the level of "concrete, significant, direct and foreseeable" in China, the principle of reasonable jurisdiction should be introduced to rationally limit them, and the rules of extraterritorial jurisdiction of securities in China should be constructed to realize the application of extraterritorial jurisdiction and ensure the efficiency of supervision [5].

\section{METHOD}

\subsection{Introduction to Z-Score Model}

Edward Altman's Z-Score Formula is a multivariate financial formula used to measure a company's financial health and to diagnose and predict the possibility of bankruptcy within 2 years. Research shows that the prediction accuracy of the formula is as high as $72 \%$ to 80\%.[4] Edward Altman, a professor at the Stern School of Business of New York University and a financial economist, observed bankrupt and non-bankrupt manufacturing enterprises in the United States in 1968, 
and established a famous 5 -variable Z-score model by using 22 financial ratios and mathematical statistics. The Z-Score model is a system based on multivariate statistical methods, taking bankrupt enterprises as samples, analyzing and judging the operation status and bankruptcy status of enterprises through a large number of experiments. Z-score model has been widely used in the United States, Australia, Brazil, Canada, Britain, France, Germany, Ireland, Japan and the Netherlands.

\subsection{Z-Score Formula}

Z-score model calculates a group of financial ratios from the financial reports of listed companies which reflect the financial crisis degree of the companies on the basis of a large number of empirical investigations and analysis studies, and then gives different weights to the warning function of the financial crisis according to these ratios, and finally obtains a company's comprehensive risk score, i.e, $\mathrm{Z}$ score, by weighted calculation. Comparing this with the critical value shows the severity of the company's financial crisis. The discriminant function of Z-Score model is:

$$
\begin{gathered}
Z=1.2 X_{1}+1.4 X_{2}+3.3 X_{3}+0.6 X_{4} \\
+0.99 X_{5}
\end{gathered}
$$

Where $\mathrm{X} 1=$ working capital/total assets, which reflects the liquidity and size characteristics of the Company's assets. If a company's working capital continues to decrease, it often indicates that the company's capital is not working properly or there is a short-term debt repayment crisis.

$\mathrm{X} 2=$ retained earnings/total assets, which reflects the Company's cumulative profitability. For listed companies, retained earnings is the balance of net profit less all dividends. The more retained earnings, the more residual ability the company has to pay dividends.

Table 1. Z-Score formula in 2018 and 2019

\begin{tabular}{|c|c|c|c|c|c|c|}
\hline Years & $\begin{array}{l}\text { Working } \\
\text { capital/ total } \\
\text { asset }\end{array}$ & $\begin{array}{l}\text { Retained } \\
\text { earnings/t } \\
\text { otal asset }\end{array}$ & $\begin{array}{l}\text { EBIT/t } \\
\text { otal } \\
\text { asset }\end{array}$ & $\begin{array}{l}\text { MV/liab } \\
\text { ility }\end{array}$ & $\begin{array}{l}\text { Sales/t } \\
\text { otal } \\
\text { asset }\end{array}$ & Z-score \\
\hline 2018 & $47.40 \%$ & $-93.28 \%$ & $1.76 \%$ & 28.48. & $24.11 \%$ & 16.65 \\
\hline 2019 & $60.40 \%$ & $-69.08 \%$ & $0.60 \%$ & 34.3. & $42.33 \%$ & 20.72 \\
\hline
\end{tabular}

$\mathrm{X} 3$ = earnings before interest and tax/total assets, i.e., EBIT / Total Assets. Can be referred to as total assets before interest and tax profit margin, and the commonly used total assets before interest and tax profit margin is EBIT / average total assets, the difference between denominators is the average total assets. The X3 is reduced when a large number of assets are purchased at the end of the period, it cannot objectively reflect the profitability of assets in one year and measure the listed company's ability to make profits by using all assets.

$\mathrm{X} 4$ = total market value of shareholders' equity/total liabilities. It measures the financial structure with the denominator being the sum of the carrying amounts of current and long-term liabilities. The numerator replaces the book value with the market value of shareholders' equity, which enables the numerator to objectively reflect the value of the company.

$\mathrm{X} 5=$ revenue from sales/total assets, i.e, total assets turnover rate, the operating capacity of an enterprise's total assets is reflected centrally in the operating level of its total assets. If the total assets turnover rate is high. It indicates that the enterprise has achieved good results in operating with all its assets. On the other hand, if the turnover rate of total assets is low, it indicates that the enterprise has poor results in operating activities with all its assets. It will ultimately affect the profitability of the enterprise.

Z-Score model comprehensively reflects the financial status of an enterprise from the aspects of asset size, liquidity, profitability, financial structure, solvency, asset utilization efficiency, etc., which further promotes the development of financial early warning system. Through the research and analysis of Z-Score model, Altman concludes that the $Z$ value is inversely proportional to the probability of financial crisis. The smaller the $Z$ value is, the more likely the company will have a financial crisis; the greater the $\mathrm{Z}$ value, the less likely the company will have a financial crisis. Altman has offered several cutoffs. When $\mathrm{Z}<1.8$, the enterprise is classified as bankrupt; when $1.8<Z<2.675$, the enterprise belongs to the "grey area" and it is difficult to draw a simple conclusion as to whether the enterprise is certain to go bankrupt; when $\mathrm{Z}>$ 2.675 , the company is in good financial condition and the probability of bankruptcy is extremely low. However, due to the different economic environments in each country and the different criteria for judging the value of each country, the critical value of corporate value varies from country to country [6-7].

\section{ANALYSIS}

\subsection{Working capital/total assets}

During the three-year period 2017-2019, the ratio of working capital/total assets of Luckin Coffee Company is rising at a speed visible to the naked eye. It is not difficult to see that this is caused by the company's internal plan, and such an abnormal growth rate makes consumers 
wonder. However, this abnormal growth rate has a lot to do with Luckin Coffee's financial fraud: First, financial fraud will erroneously report the company's sales revenue and sales profit, so the working capital/total assets ratio will also be different.

This is mainly because the overall risk awareness is not enough.

The operating performance pressure of listed companies comes from refinancing and market value [8]. Some companies are very much looking forward to maintaining their performance during the review period in order to successfully pass the review and issuance and listing; companies that bring in external capital, are often eager to complete the bet against the performance of investment institutions. So, many companies are facing life-and-death performance pressure. Therefore, falsely increasing the ratio of working capital to total assets can improve the company's own resilience on the surface, but its inherent financial risks should not be underestimated.

\subsection{Retained income/total assets}

The retained earnings will also be fraudulent, and Luckin Coffee will also increase its revenue, which may increase the retained earnings/total assets ratio to achieve a numerical change. Experienced financial personnel only need to calm down their minds, believe in common sense, and pass financial supervision, it is not very difficult to find signs of fraud, and even catch fraud. However, whether it is an audit, an investment bank, or an investment institution that pays for it, it is very popular.

The target company is often in a relatively weak position. In most cases, when fraud can be identified, the financial staff has invested a lot of time in their work and energy, subjectively, he is unwilling to give up the opportunity to deal with customers easily. As a circumstance, they begin to lie about their retained earnings, comforting themselves and saying any businesses are risky. If you don't take certain risks, your business will be completely lost. The solution is done; although there is a problem with this, the customer also has "difficulties", as long as the problems found are corrected, the same mistakes will not be made later, and the risk will be controlled and endured.

\subsection{Pre-interest and tax/total assets}

Profit before interest and taxes $=$ net profit of the company + interest expense paid by the company + income tax paid by the company

or

Earnings before interest and taxes $=$ fixed income marginal operating costs $=$ sales revenue-variable costsfixed costs

The profit before interest and tax is mainly used for calculation, for example:

Regardless of business profit, debt interest and preferred stock dividends are fixed. When the profit before interest and taxes increases, the fixed financial expenses borne by each dollar of surplus will be relatively reduced, which can bring more surplus to common shareholders. Therefore, increasing the ratio of preinterest profit and pre-tax profit to total assets will also make more investors and consumers fall in love with it, thus creating the illusion that Luckin is a good company.

\subsection{MV/Liabilities}

Successfully landed on Nasdaq in the United States on May 19, 2019, it only took one year and eight months from establishment to listing, setting the world record for the fastest time to market on Nasdaq. From the 17-monthold company to the IPO, from being attacked by shortsellers to disclosing forged financial data, Luckin Coffee fell into the altar overnight. Qian Zhiya, the Chief Executive Officer of Luckin Coffee at the time, announced that by the end of 2019, Luckin, with 4507 directly-operated stores, had officially become the largest brand in the Chinese market. However, since 2020, Luckin has only 186 new coffees, a growth rate of $-80.6 \%$ compared to the same period last year.

Luckin has the highest market value of coffee stocks. Since the release of the financial report for the third quarter of 2019, the stock price of Luckin Coffee has been at a record high. On November 26, 2019, Luckin Coffee's share price reached 32 Hong Kong dollars, 88\% higher than the issue price at the time of listing, and the market value of Luckin Coffee's share price reached 7.69 billion U.S. dollars. According to the financial report, Luckin Coffee's revenue in the third quarter of 2019 was RMB 1.5416 million (approximately US\$215.7 million), an increase of $540.2 \%$ over the same period last year.

Luckin Coffee's net loss in the third quarter was RMB 531.9 million (approximately US\$74.4 million), compared with RMB 484.9 million in the same period last year. The cumulative number of Luckin coffee trading customers in the third quarter increased from 6 million at the end of the third quarter of 2018 to 30.7 million, an increase of $413.4 \%$. Luckin Coffee market value is around 321 million US dollars.

Luckin Coffee's average monthly number of trading customers in the third quarter increased by $397.5 \%$ compared to the third quarter of 2018. As of the end of the third quarter, the total number of stores was 3680 , an increase of 209.5 percent from the 1,189 at the end of the previous quarter. The third quarter of 2018. In the third quarter, the average net income of Luckin Coffee's products per store increased by $79.5 \%$ in the third quarter of 2018 . 


\subsection{Sales/Total Assets}

Luckin Coffee disclosed that an internal investigation found that its $\mathrm{COO}$ fabricated about 2.2 billion yuan (\$310 million) in sales. After the release of the document, the company's stock price fell by more than $80 \%$ in premarket trading, and fell by $75 \%$ as of the close of trading.

For coffee companies like Luckin Coffee, normal extended procedures are difficult to complete. It is very difficult to live fraud. For example, the fraud of "swiping orders" in the catering industry is a hot spot, "swiping orders" has been regularized, streamlined and organized. "Swipe the order" is an improper marketing method under the Internet environment, but the objective result is an out-and-out financial fraud that companies pay for profits on their own. Then, the company's own sales volume was continuously increased, and even a new third board company disclosed in its public transfer specification that there was a large-scale "scaling". If this critical evidence is not guaranteed by professional means, it is impossible for financial personnel to do a good job of financial analysis of certain special industries. Such a method to increase sales is not a very good method, it will only increase the company's financial risk.

\section{FURTHER DISCUSSION}

\subsection{Delist from the US stock market.}

Since the establishment of Luckin business stability, the highest share price reached 50.02 yuan. However, the stock price in 2020 occurred a precipitous decline, until now 1.38 yuan, resulting in this result is the direct cause of the financial fraud Luckin exposure. The fraud is a breach of trust that can not be tolerated in the market. It causes consumers to lose trust in the company, and the corresponding demand for its shares will decrease, resulting in a drop in the share price. It also causes the company to be plagued by lawsuits and huge fines, and eventually delisted from Nasdaq.

\subsection{Damage the corporate image}

The exposure of financial fraud broke the good image of Luckin since its establishment, making it lose credit totally and fall into litigation cases, which resulted in an increase in goodwill risk. As a domestic emerging coffee company, Luckin was expected. The consequences of this fraud are very serious, not only affect Luckin's own reputation, but also in China and even China's reputation has had a great negative impact. Corporate social responsibility may be one alternative solution for the impaired firm image [9].

\subsection{The impact on Chinese firms}

The outbreak of the Luckin incident not only brought about a serious crisis of confidence and punishment for the company, but also greatly worsened the foreign listed companies, the credibility of the obvious decline, reputation risk increased. The financial fraud by Luckin has had a negative impact on other Chinese companies listed in the US, not only the listed companies but also their share prices, making it even more difficult for unlisted companies. On the one hand, for listed companies, the financial frauds of one china-listed stock will reflect through the investor's market that this channel will cause negative externalities to other China-listed stocks, this is reflected in the abnormal fluctuations in the share prices of China's listed companies. In the wake of the Luckin incident, the market performance of China's and Taiwan's stocks became increasingly unfavorable, the yield began to show negative values, and the credibility of China's and Taiwan's stocks was significantly damaged. On the other hand, when a crisis of trust arose, Chinese companies wishing to go public in the United States might come at a greater cost.

\section{CONCLUSION}

Through the research of Z-score model, we can find that the bankruptcy probability of Luckin coffee is still very high. As far as the current situation is concerned, the financial fraud in Luckin coffee has a great impact on the company, but it is not devastating. If Luckin coffee cannot change its development strategy and innovate its business model, but continue to expand at a high speed, it will not be able to tide over the difficulties so easily next time. Through this incident, it is believed that the management of the enterprise can correctly realize the drawbacks of the rapid development mode of relying on external financing. In the next few years, Luckin enterprise, which has changed its development mode, will become one of the most outstanding enterprises in China's coffee industry.

This would also of value for expansion decision for E-commerce in the chain store market [10].

\section{REFERENCES}

[1] Zhang Xinmin, Chen Deqiu, Business Model, Value Co-creation and Governance Risks of Enterprises in the Mobile Internet Era - - A case study of financial fraud of Luckin coffee. Management World 36 (05): 74-86+11.

[2] Yang Ying. Luckin coffee financial fraud case analysis-based on the perspective of financial analysis [J]. market weekly, 2020,33(11):107-109.

[3] Wang, Qiyao. 2020. "Cost of the Accounting Scandal of Luckin Coffee to Multiple Aspects and the Influence Under Current Economy and Pandemic Time." In. https://doi.org/10.2991/aebmr.k.201128.035. 
[4] Wang Xiaoyan, Chen Ting. The impact of financial fraud of listed companies in China-based on the perspective of blockchain $[\mathrm{J}]$. Accounting newsletter, 2019(28):110-114.

[5] Cao Ming. Study on the Construction of China's Securities Extraterritorial Jurisdiction Rules Taking Luckin coffee Financial Fraud as the breakthrough point $[\mathrm{J} / \mathrm{OL}]$. Southern Finance: 19[2021-04-03].

[6] Altman, Edward I. 1968. "Financial Ratios, Discriminant Analysis and the Prediction of Corporate Bankruptcy." The Journal of Finance 23 (4): 589-609.

[7] Altman, Edward I., Małgorzata IwaniczDrozdowska, Erkki K. Laitinen, and Arto Suvas. 2017. "Financial Distress Prediction in an International Context: A Review and Empirical Analysis of Altman's Z-Score Model." Journal of International Financial Management \& Accounting 28 (2): 131-71.

[8] Johnson, Shane A., Harley E. Ryan Jr., and Yisong S. Tian. 2009. "Managerial Incentives and Corporate Fraud: The Sources of Incentives Matter*." Review of Finance 13 (1): 115-45.

[9] Liao, Lin, Guanting Chen, and Dengjin Zheng. 2019. "Corporate Social Responsibility and Financial Fraud: Evidence from China." Accounting \& Finance 59 (5): 3133-69.

[10] Kleisiari, Christina, Marie-Noelle Duquenne, and George Vlontzos. 2021. "E-Commerce in the Retail Chain Store Market: An Alternative or a Main Trend?" Sustainability 13 (8). 